\title{
TU/e EmonONEN

\section{The role of axial chirality in Schiff bases of pyridoxal phosphate and amino acids in the mechanism of racemase enzyme : a quantum-chemical study}

Citation for published version (APA):

Genderen, van, M. H. P., \& Buck, H. M. (1989). The role of axial chirality in Schiff bases of pyridoxal phosphate and amino acids in the mechanism of racemase enzyme : a quantum-chemical study. Recueil des Travaux Chimiques des Pays-Bas, 108(11), 413-417. https://doi.org/10.1002/recl.19891081105

DOI:

10.1002/recl.19891081105

Document status and date:

Published: 01/01/1989

Document Version:

Publisher's PDF, also known as Version of Record (includes final page, issue and volume numbers)

Please check the document version of this publication:

- A submitted manuscript is the version of the article upon submission and before peer-review. There can be important differences between the submitted version and the official published version of record. People interested in the research are advised to contact the author for the final version of the publication, or visit the DOI to the publisher's website.

- The final author version and the galley proof are versions of the publication after peer review.

- The final published version features the final layout of the paper including the volume, issue and page numbers.

Link to publication

\footnotetext{
General rights

- You may freely distribute the URL identifying the publication in the public portal. follow below link for the End User Agreement:

www.tue.nl/taverne

\section{Take down policy}

If you believe that this document breaches copyright please contact us at:

openaccess@tue.nl

providing details and we will investigate your claim.
}

Copyright and moral rights for the publications made accessible in the public portal are retained by the authors and/or other copyright owners and it is a condition of accessing publications that users recognise and abide by the legal requirements associated with these rights.

- Users may download and print one copy of any publication from the public portal for the purpose of private study or research.

- You may not further distribute the material or use it for any profit-making activity or commercial gain

If the publication is distributed under the terms of Article 25fa of the Dutch Copyright Act, indicated by the "Taverne" license above, please 


\title{
The role of axial chirality in Schiff bases of pyridoxal phosphate and amino acids in the mechanism of racemase enzymes. A quantum-chemical study
}

\author{
Marcel H. P. van Genderen and Henk M. Buck \\ Department of Organic Chemistry, Eindhoven University of Technology, P.O. Box 513, \\ $5600 \mathrm{MB}$ Eindhoven, The Netherlands \\ (Received April 25th, 1989)
}

\begin{abstract}
In the enzymatic racemization of $\mathrm{L}$ and $\mathrm{D}$ amino acids, the coenzyme pyridoxal phosphate (PLP) forms a Schiff base with the amino acid. In the first step of the isomerization reaction, both the L and D PLP-amino acid compounds are deprotonated by a single basic site in the enzyme, which is normally assumed to occur via large conformational changes of coenzyme or enzyme. We propose a more efficient mechanism in which axial chirality is introduced into the PLP-amino acid complex by a rotation around the $\mathrm{C} 4-\mathrm{C}^{\prime}$ ' bond, placing the iminium side-chain in an out-of-plane orientation. This allows optimal location of both $\mathrm{L}$ and $\mathrm{D}$ amino acids for deprotonation by one basic site in the enzyme. A combination of the calculated results with the kinetic data of Faraci and Walsh (Biochemistry 27, 3267 (1988)) provides insight into the location of the catalytic base in the enzyme with respect to the coenzyme.
\end{abstract}

\section{Introduction}

Pyridoxal phosphate (PLP) is an essential coenzyme for various enzymatic conversions of amino acids, such as racemization, transamination and decarboxylation. In all these reactions, the active complex is a Schiff base formed between PLP and an amino acid of either L or D configuration. The enzymatic racemization of amino acids is of special interest, since D amino acids, which are essential for the synthesis of bacterial cell walls and membrane transport proteins such as gramicidin, can only be obtained via isomerization of the natural $L$ amino acids. During the racemization reaction, the PLP-amino acid aldimine compound is deprotonated at $\mathrm{C} \alpha$, resulting in a quinonoid carbanion structure ${ }^{1}$. Reprotonation at the other side is now necessary in order to give an aldimine with a different configuration. In the commonly accepted mechanism, both the aldimine and the quinonoid compounds are planar, due to intramolecular hydrogen bonding and conjugation of double bonds, respectively (see Scheme 1). Although the structure of the active site in the enzyme is still unknown in detail, experimental evidence from various groups ${ }^{2-6}$ has demonstrated unequivocally that only a single basic site in the acemase enzyme is involved in the (de)protonation reactions. It is therefore usually assumed that either the base is highly mobile or that the complete PLP-amino acid omplex moves within the active site of the enzyme swinging-door mechanism ${ }^{7}$ ).

We now wish to offer an alternative mechanism for the nzymatic amino acid racemization, which involves nonlanar conformations of the aldimine systems. This suggestion is inspired by our work on the coenzyme redox ouple $\mathrm{NAD}^{+} / \mathrm{NADH}$, where an out-of-plane conformation f the carbonamide moiety occurs in the active site of a

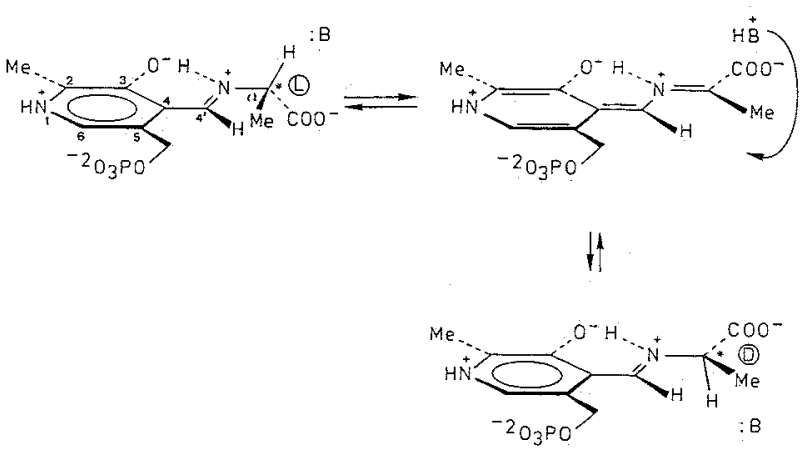

Scheme 1. Standard representation of the racemization mechanism of PLP-amino acid complexes in racemase enzymes.

dehydrogenase enzyme $e^{8,9}$. The orientation of the carbonyl dipole then selects the hydrogen which is transferred from the coenzyme to a substrate, or vice versa ${ }^{10}$. For the PLP-amino acid aldimines, axial chirality is introduced via a rotation around the $\mathrm{C} 4-\mathrm{C} 4^{\prime}$ bond, which positions the iminium side-chain out of the plane of the pyridinium ring. Efficient access to a single basic site is now possible for both $\mathrm{L}$ and $\mathrm{D}$ amino acids, when different iminium out-ofplane orientations are present for each configuration (see Scheme 2). Therefore, the racemization process can occur with a minimum of conformational changes.

It will be shown, for the PLP-amino acid aldimine systems using quantum-chemical calculations on the MNDO level, that out-of-plane orientations of the iminium group can easily be accomplished by the enzyme. The deprotonation of L- and D-aldimine compounds has been studied theoretically by calculations based on the quinonoids which are formed from the non-planar aldimines. The results of 


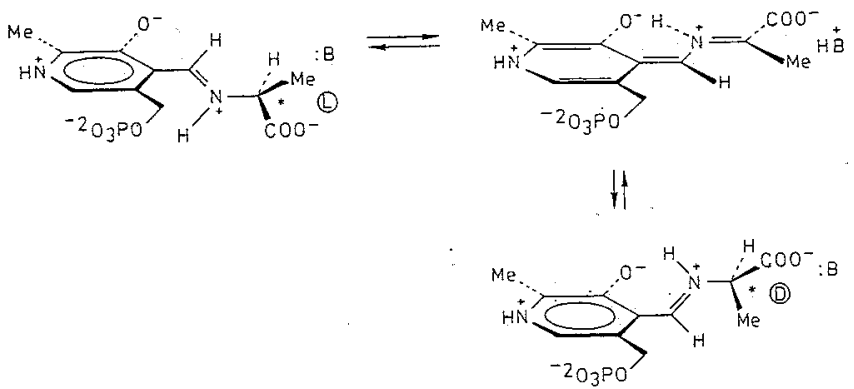

Scheme 2. Alternative mechanism for the racemization, involving non-planar conformations of the PLP-amino acid complexes.

these calculations are in good agreement with the kinetic data of the group of Faraci and Walsh ${ }^{2}$ concerning the protonation and deprotonation processes in alanine racemases.

\section{Methods and definitions}

$\mathrm{MNDO}^{11}$ calculations were performed using the AMPAC program $^{12}$ and involved geometry optimization of all variables, except the ring conformation, which is assumed to be always planar, and the conformations of the 3-hydroxyl and 5-methylene phosphate groups. The latter moieties were kept in a symmetric orientation with respect to the ring (see Fig. 1). This conformation was chosen to prevent a priori favouring of one of the out-of-plane orientations.

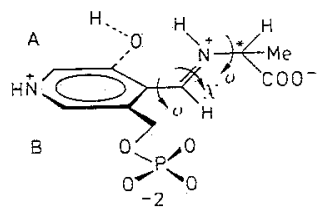

Fig. 1. Model systems for the PLP-alanine aldimines as used in the MNDO calculations, with definitions of the iminium side chain torsion angles and of the $A$ and $B$ sides of the pyridinium ring.

It has been found that the presence of the 2-methyl group is unnecessary for the activity of the coenzyme ${ }^{13}$ and it has therefore not been included in the calculations. The amino acid alanine is used as a model system, since it is the smallest chiral amino acid and has been studied extensively for enzymatic racemizations involving PLP ${ }^{1}$. The 3-hydroxyl group is usually deprotonated in the coenzyme and forms a hydrogen bond with the iminium nitrogen. Since this is the major reason for planarity in the aldimines, we carried out the calculations with a neutral hydroxyl to simulate an enzymatic interaction which allows out-of-plane orientation of the iminium group. However, it was found in additional calculations that, even for a deprotonated hydroxyl group, a non-planar conformation is possible, although the deviation from planarity is less ${ }^{14}$. The relevant torsion angles in the iminium side-chain (see Fig. 1) are designated $\phi$ $\left(\mathrm{C} 3-\mathrm{C} 4-\mathrm{C} 4^{\prime}-\mathrm{N}\right), \quad \mathrm{x} \quad\left(\mathrm{C} 4-\mathrm{C} 4^{\prime}-\mathrm{N}-\mathrm{C} \alpha\right)$ and $\psi$ $\left(\mathrm{C} 4^{\prime}-\mathrm{N}-\mathrm{C} \alpha-\mathrm{COO}^{-}\right)$and follow the standard sign convention $^{15}$. For the aldimines, $\mathrm{x}$ is always found to be $180^{\circ}$ (C4 trans to $\mathrm{C} \alpha$ ) for steric reasons. The $\mathrm{C} 4-\mathrm{C}^{\prime}$ conformation determines the out-of-plane character of the iminium group, which is designated "up" $\left(\phi=90^{\circ} \pm 90^{\circ}\right)$ when $N$ is on the A side ${ }^{16}$ of the ring, or "down" $\left(\phi=-90^{\circ} \pm 90^{\circ}\right)$ for $\mathrm{N}$ on the $\mathrm{B}$ side ${ }^{16}$. The orientation of the amino acid is given by $\psi$ and is chosen in such a way that the $\mathrm{C} \alpha-\mathrm{H}$ bond is perpendicular to the $\mathrm{C}=\mathrm{N}$ bond, as is required for depro. tonation according to the work of Dunathan ${ }^{17}$. Two orientations are possible, viz. the proton on the si-side ${ }^{18}$ of the $\mathrm{C}=\mathrm{N}$ bond $\left(\psi=150^{\circ}\right.$ for $\mathrm{L} ; \psi=30^{\circ}$ for $\left.\mathrm{D}\right)$, or on the re-side ${ }^{18}\left(\psi=-30^{\circ}\right.$ for $L ; \psi=-150^{\circ}$ for $\left.D\right)$. An aldimine system is therefore characterized by the amino acid configuration and the $\phi$ and $\psi$ conformations (e.g., L,down,si). In the quinonoid systems (see Fig. 2), $\mathrm{C} 4-\mathrm{C}^{\prime}$ and $\mathrm{N}-\mathrm{C} \alpha$ are double bonds, which can only have cis or trans configurations. The $\mathrm{C}^{\prime}-\mathrm{N}$ bond does not deviate significantly from planarity in the calculations, thus the combination of $\phi$ and $\psi$ is used to characterize the quinonoids (e.g., cis, trans).

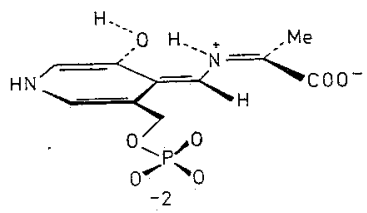

Fig. 2. Model systems for the PLP-alanine quinonoids, re. sulting from deprotonation of the aldimines.

\section{Results and discussion}

For both the $\mathrm{L}$ and $\mathrm{D}$-aldimines, it was found, after energy minimization, that out-of-plane orientations of the iminium side-chain are favoured over planar conformations independent of the initial conformation (see Table I). This tendency is not merely an artifact of the calculation, since several $\mathrm{X}$-ray crystal structures of pyridoxal-amino acid compounds display non-planar conformations with $\phi$ ranging from $10^{\circ}$ to $20^{\circ} 19-23$, although a metal ion is chelated to both the 3-hydroxyl and the iminium nitrogen, which is expected to favour a planar situation. According to our calculations, the most stable out-of-plane conformation

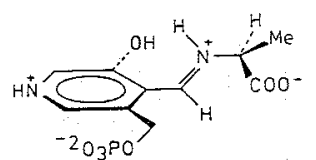

L, up, re

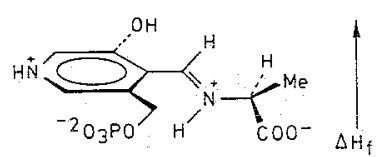

L, down,si

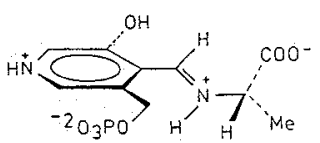

L. down,re

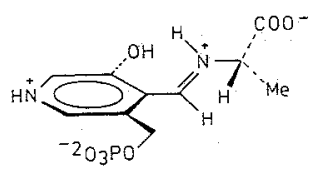

L. up.si

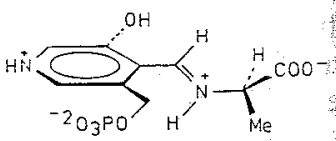

D. down.si

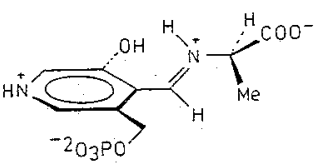

D. up.re

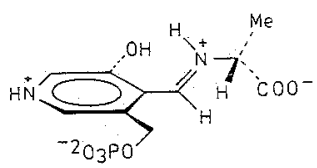

D.uṕ.si

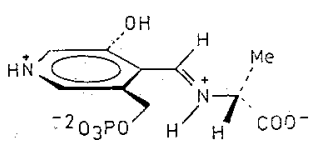

D. down,re
Fig. 3. Conformations of the energy-minimized PLP-alanine aldimines, in order of the enthalpy of formation. 
ro-

en-

the

the

ine

igu-

. In

are

igu-

atly

1 of

$\therefore g$,

re-

\section{pyridinium ring. X-ray crystal structures and circular} dichroism spectroscopy have shown that the carbonyl orientation is completely determined by the chirality in the amine substituent ${ }^{24}$

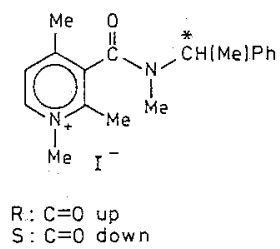

For the aldimine systems, the relation between the axial chirality and the amino acid configuration has as a consequence the fact that the $\mathrm{C} \alpha-\mathrm{H}$ bond points in the same direction for both $\mathrm{L}$ - and D-aldimines of equal stability (see Fig. 3). This fits very well with the experimental evidence that only a single basic site is present in the enzyme, which can deprotonate both amino acid isomers without gross structural changes in either the enzyme or the PLP-amino acid complex.

In order to determine the actual conformation of the aldimine which is deprotonated, and thereby the location of the basic site relative to the coenzyme, we have also studied the different quinonoids formed after abstraction of $\mathrm{H} \alpha$. As can be seen from Table II and Fig. 4, the most stable quinonoid, which is formed from four of the aldimines, maximizes the distance between the negatively charged carboxylate and phosphate groups by a cis, trans configuration in the iminium side-chain.

Inspection of the enthalpy decrease after deprotonation (see Table II) reveals that the removal of $H \alpha$ is thermodynamically most favourable for the L,down,si and D,up,re aldimines. Although these conformations are not the most

Table II Energy-minimized conformations of the quinonoid carbanions after deprotonation of the aldimines.

\begin{tabular}{|l|l|l|l|l|}
\hline \multirow{2}{*}{ Aldimine } & \multicolumn{4}{|c|}{ Resulting quinonoid } \\
\cline { 2 - 5 } & $\mathrm{C} 4-\mathrm{C}^{\prime}$ & $\mathrm{N}-\mathrm{C} \alpha$ & $\Delta H_{\mathrm{f}}^{\mathrm{a}}(\mathrm{kcal} / \mathrm{mol})$ & $\Delta H_{\mathrm{deprot}}^{\mathrm{b}}(\mathrm{kcal} / \mathrm{mol})$ \\
\hline L,up,si & cis & trans & -152.89 & -41.63 \\
D,down,re & trans & trans & -152.77 & -41.50 \\
\hline L,down,si & cis & trans & -152.87 & -44.41 \\
D,up,re & cis & cis & -154.09 & -45.61 \\
\hline L,down,re & trans & cis & -147.61 & -37.03 \\
D,up,si & trans & cis & -140.99 & -37.02 \\
\hline L,up,re & cis & -140.88 & -34.98 \\
D,down,si & cis & & -34.93 \\
\hline
\end{tabular}

Enthalpy of formation. $\quad$ b Enthalpy difference between initial áldimine and resulting quinonoid systems. 
<smiles>CC(=N/C=C1/C(O)=CNCC1O)C(=O)[O-]</smiles>

cis, cis
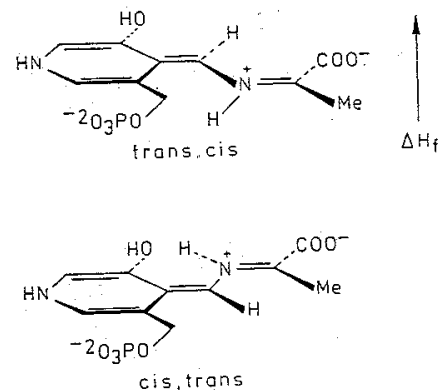

Fig. 4. Conformations of the energy-minimized PLP-alanine quinonoids, in order of the enthalpy of formation.

stable, they are the most reactive. It is reasonable to assume that the racemase enzyme can induce a somewhat less favourable out-of-plane orientation ( $c a .3 \mathrm{kcal} / \mathrm{mol}$ ), e.g., by the formation of a hydrogen bond with the carboxylate group, to gain reactivity. Based on this assumption, we conclude that the basic site of the enzyme is located on the 3-hydroxyl side of the PLP-amino acid complex.

A more detailed interpretation of the calculational results can be performed by using the experimental results of Faraci and $W a l s h^{2}$ on the kinetics of the various (de)protonation steps in alanine racemases. It was found for $D$ amino acids that both abstraction of $\mathrm{H} \alpha$ and reprotonation of the quinonoid to give a D chirality are markedly slower compared to the same processes for $\mathrm{L}$ amino acids. This indicates a more favourable location of the basic site for the $\mathrm{L}$-aldimine compound. Since our calculations indicate that, in the active $\mathrm{L}$,down, si conformation, the $\mathrm{C} \alpha-\mathrm{H}$ bond points upwards (see Fig. 5), it seems reasonable to assume that the basic site is located on the A side of the ring, in line with the bond to be broken. Deprotonation of the D,up,re aldimine with a downward $\mathrm{C} \alpha-\mathrm{H}$ bond will then be more difficult. Reprotonation of the cis, trans quinonoid to an $\mathrm{L}$ configuration will be likewise easier than reprotonation to a D configuration, when the proton-donating site is above the ring.

Therefore, both the experimental and theoretical results are in good agreement with a location of the basic site in alanine racemases, being on the 3-hydroxyl side of the coenzyme, slightly above the ring on the A side.

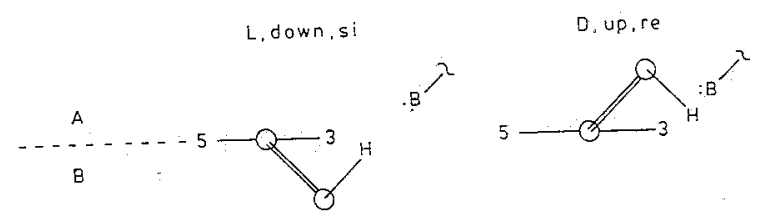

Fig. 5. Schematic representation of the proposed orientation of the catalytic base in alanine racemase for the $L$ - and $D$-aldimines.

\section{Concluding remarks}

Based on the above results, it is proposed that out-of-plane conformations in PLP-amino acid complexes can play an important role in the mechanism of enzymatic racemization of amino acids. For both $L$ and $D$ amino acids, the first deprotonation step can be facilitated by offering the $\mathrm{H} \alpha$ proton to the single basic site in a non-planar conformation. Using kinetic data on the deprotonation, a prediction is made for the precise location of the base in the active site of the enzyme. The correlation between side-chain chirality and the axial chirality in pyridoxal phosphate directs these processes. Preliminary conformational studies on pyridoxal model compounds provide evidence for the proposed re. lationship ${ }^{25}$.

Since deprotonation of $\mathrm{C} \alpha$ in a PLP-amino acid aldimine is also the first reaction step in transamination reactions, we intend to carry out further studies in order to investigate the impact of axial chirality on the mechanism present in trans. aminase enzymes, which are highly specific for either $L$ or $D$ amino acids. Theoretical studies should provide insight into the process of reprotonation of the quinonoids at $\mathrm{C} 4$, which occurs in transamination, while model systems with a permanent axial chirality will be synthesized for conformational studies.

\section{References}

${ }^{1}$ K. Soda, H. Tanaka and $K$. Tanizawa in "Vitamin $\mathrm{B}_{6}$ Pyridoxal Phosphate", D. Dolphin, R. Poulson and O. Avramović, Eds., Wiley, New York, 1986, Ch. 7.

2 W. Faraci and C. T. Walsh, Biochemistry 27, 3267 (1988).

${ }^{3}$ D. Roise, K. Soda, T. Yagi and C. T. Walsh, Biochemistry 23, 5195 (1984).

4 G. L. Kenyon and G. D. Hegeman, Adv. Enzymol. Relat. Areas Mol. Biol. 50, 325 (1979).

5 T. R. Sharp, G. D. Hegeman and G. L. Kenyon, Biochemistry 16, 1123 (1977).

${ }^{6}$ C. P. Whitman, G.D. Hegeman, W.W. Cleland and G. $L$ Kenyon, Biochemistry 24, 3936 (1985).

7 L. L. Henderson and R. B. Johnston, Biochem. Biophys. Res. Commun. 68, 793 (1976).

8 N. A. Beijer, H.M. Buck, L. A. AE. Sluyterman and E.M. Meijer, Biochim. Biophys. Acta, submitted.

${ }_{9 \mathrm{a}}$ H. Eklund, J. P. Samama and T. A. Jones, Biochemistry 23 , 5982 (1984);

${ }^{\mathrm{b}}$ T. Skarzynski, P. C. E. Moody and A. J. Wonscott, J. Mol. Biol 193, 171 (1987).

${ }^{10 a}$ M. C. A. Donkersloot and H.M. Buck, J. Am. Chem. Soc. 103, 6554 (1981);

' $P . M . T$. de Kok, L.A.M. Bastiaansen, P.M. van Lier, J. A.J.M. Vekemans and H. M. Buck, J. Org. Chem. 54, 1313 (1989).

11 M.J.S. Dewar and W. Thiel, J. Am. Chem. Soc. 99, 4899 (1977).

12 Quantum Chemistry Program Exchange No. 506.

13 F. Masugi, Y. Natori, S. Shimizu and S. Fukui, Biochim Biophys. Acta 320, 648 (1973).

14 Geometry optimization of the L-aldimine system with a si-oriented amino acid was achieved using a deprotonated 3-hydroxyl group, starting from a syn conformation of the iminium nitrogen and the hydroxide $\left(\phi=0^{\circ}\right)$. An out-of-plane iminium nitrogen $35.2^{\circ}$ (up) resulted, which is somewhat lower than the $57.4^{\circ}$ found in the $3^{\prime}$-protonated system (see Table II). W. Klyne and V. Prelog, Experientia 16, 521 (1960).

16 G. C. Ford, G. Eichele and J. N. Jansonius, Proc. Natl. Acad. Sci. USA 77, 2559 (1980).

${ }^{17 a}$ H. C. Dunathan, Proc. Natl. Acad. Sci. USA 55, 712 (1966);

${ }^{b}$ H. C. Dunathan, Adv. in Enzymol. 35, 79 (1971).

${ }^{18 a}$ K. R. Hanson, J. Am. Chem. Soc. 88, 2731 (1966);

${ }^{b}$ H. Hirschmann and K. R. Hanson, Tetrahedron 30, 3649 (1974).
19. $F . B$ Chin

${ }^{20} H . N$

66, 2

${ }_{21}$ S.P.

2051

${ }^{22} \mathrm{~K} . \mathrm{A}$

(198:

${ }^{23}$ E.

85,1 
${ }^{19}$ F. Bigoli, M. Lafranchi, E. Laprati and M. A. Pellinghelli, Inorg. Chim. Acta 80, 135 (1983).

${ }^{20}$ H. M. Dawes, J. M. Waters and T. N. Waters, Inorg. Chim. Acta 66, 29 (1982).

${ }^{21}$ S. P. S. Rao and H. Manohar, J. Chem. Soc., Dalton Trans. 2051 (1985).

${ }^{22}$ K. Aoki and H. Yamazaki, J. Chem. Soc., Chem. Commun. 410 (1984).

${ }^{23}$ E. Willstadter, T. A. Hamor and J. L. Hoard, J. Am. Chem. Soc. 85, 1205 (1963).
${ }^{24 a}$ L. A. M. Bastiaansen, J. A. Kanters, F. H. van der Steen, J. A. C. de Graaf and H. M. Buck, J. Chem. Soc., Chem. Commun. 536 (1986);

${ }^{b}$ L. A. M. Bastiaansen, T.J.M. Vermeulen, H. M. Buck, W.J.J. Smeets, J. A. Kanters and A. L. Spek, J. Chem. Soc., Chem. Commun. 230 (1988).

${ }^{25}$ M. H. P. van Genderen, P. M. van Lier and H. M. Buck, Recl. Trav. Chim. Pays-Bas, following paper. 